\title{
Introduction On Adam's House in the Pacific
}

\author{
Ross Jenner
}

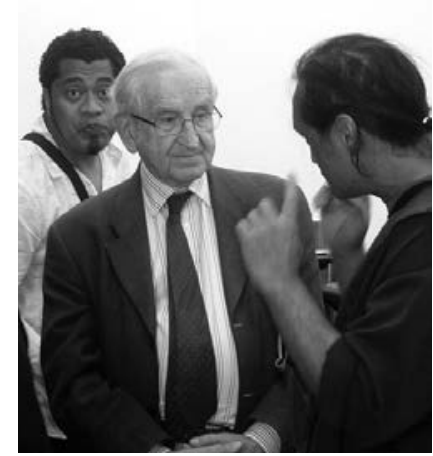

If, in this part of the world, the context is defined as paradisiacal, what is the need for architecture? Is it enough that building in such circumstances be as little mediated, as natural, as possible? How does architecture become dependent on this natural context? What is the Pacific, which is invoked in the guise of a scene or site to safeguard a paradise and to define a natural architecture? Idyllic, remote and untouched parts, where architecture is barely needed, seem to summon up notions of original dwelling from their very surroundings in forests, glades, clearings, mountains, beaches, lakes and deserts. They summon up the primitive in the form of sheds, cabins and even villas and tourist resorts, which assemble sources for the uncorrupted hut.

Why does the private or single family house gain importance within such a primal setting, as it seems to in Australasia? Does the proliferation of books on the house signify that this is the sole local discourse? How does this demand for native traits measure against the original dwellings, such as whare and fale? Where do they fit? How do they fit? What has been the role of the discourse of appropriation? The primitive hut seems to provide the basis of a natural perception, uncluttered by cultural baggage where only innate ideas and external necessities prevail in the pursuit of ever purer tectonics and returns to origins.

This, the tenth, issue of Interstices derives more or less from a symposium in honour of Joseph Rykwert held at the University of Auckland in November 2008 on the occasion of his stay as Distinguished Visitor to the School of Architecture and Planning. The questions above and those which follow were posed in an attempt, in the form of both academic papers and architects' examinations of their own work, to re-assess what significance the house, the natural, raw shelter and beginnings and other Australasian obsessions might still have in today's architectural culture.

As Rykwert argued over 30 years ago in On Adam's House in Paradise: The Idea of the Primitive Hut in Architectural History (1972), the primitive hut provides an image of perpetual reconstruction, a paradigm of building and renewal by return to origins. But perhaps this primitive hut could also be encountered as an exorbitant cultural accumulation of concerns with natural origins, derivative of a Rousseau-inspired Eurocentrism, an overly cluttered baggage of cultural assumptions and idealisms. Since the publication of Adam's House, discourses of architecture have engaged in a panoply of critical concerns that question the search for origins and the existence of simple natures. Would Adam's house, for example, survive the tremors of Grammatology? Could a radical understanding of communitarian ethics be derived from the Hut's primitive and essential 
nature? In what ways are these themes still alive and relevant today? What modes of renewal, return, persistence and continuity exist in today's architecture here? What further contribution could be made to the theme of Adam's House?

Many questions remain unanswered but, in the attempt, a line of thought-provoking papers emerged. In "Whiteness, Smoothing and the Origin of Samoan Architecture," Albert Refiti explores the idea of origin in Samoan architecture by focusing on the attempt in Samoan craft to dress and smoothmaterials in the layout and construction of architecture. In Samoa, he argues, what is considered architecture (which has recourse to the first house), must be dressed and be smoothed out. This is not because of a fascination with a "return to origins,", rather, it has to do with what Samoans considered "proper" or teu, which allows things to be put in order so that they turn towards the ancestors. Space-making in Samoan is inclined towards the production of things that are of whiteness, smoothness and openness because these are to be placed before the ancestors and the community. Therefore, things-towards-the-ancestors must have a directionality and smoothing out that binds together the past and the present.

Likewise, Charmaine 'Ilaiu, in her "Tauhi Vā: the first space," also finds Rykwert's Primitive Hut, as an image of perpetual reconstruction, only tenuously relevant to the Tongan fale. She argues that, whereas Rykwert seems to place emphasis on the sheer physicality and imagery of a structure, the domestic fale in Tonga engages an essential space that, in many respects, exceeds architecture as that which begins between people. Tongans call this concept tauhi $v \bar{a}-$ maintaining beautiful social relations. As the 'first' and most enduring space, tauhi $v \bar{a}$ 'makes,' rather than 'builds,' Tongan domestic architecture. 'Making,' she argues, is more appropriate than simple 'building,' since tauhi $v \bar{a}$ can permeate the different stages of the fale's realisation: conception, organisation on site (internally and externally), materialisation and building ethic.

By contrast, Mike Austin and Jeremy Treadwell in "Constructing the Pacific Hut" find that a search for a history and theory of architectural origins, such as Rykwert examines, is characterised by propositions of foundational acts and technological moments. Common to these moments are the ideas of the unsheltered human, the necessity for enclosure and the notion of a technical and creative genesis. Rykwert's discussion of the Japanese Ise temple seems to suggest that other circumstances might apply. This paper argues that, in the Pacific, an architecture emerged from mobility and a desire for openness. Connecting the tectonics of the Pacific building to the technology of the canoe, they consider some examples of the ridge beam and its supports (or lack of) on houses from Samoa and Papua New Guinea.

Nevertheless, paradise continues to inspire the general and architectural imagination. In "Take me away ... In search of original dwelling," Tina EngelsSchwarzpaul and Keri-Anne Wikitera argue that through elaborate, purposebuilt complexes, or de- and re-contextualised single buildings, "the performative primitive" (Dean MacCannell) is still being staged as a form of 'iconic architecture.' Alongside an exclusive resort in Upolo, Samoa, they explore the histories of several Māori whare and Samoan fale which travelled the world's exhibitions and museums from the 1860s on. Before the mid-twentieth century, houses were usually taken away without much consultation with, let alone involvement from, their original communities. From the 1960s, as tourism and leisure industries expanded to an unprecedented extent, exhibitions of 'traditional' dwellings in 
modern "edutainment" contexts perpetuated the earlier exhibition of exotic others. The buildings, however, were often no longer built for community purposes but pre-fabricated in their countries of origin for display overseas. The 'natives,' as it were, now colluded with an ongoing Western quest for origins and a yearning for authenticity and Paradise.

Paul James and Robin Skinner in "Sites of Defence within Picturesque Scenes: Late eighteenth century representations of natural architecture in New Zealand" explore the tension between competing attitudes influencing early representations of the New Zealand landscape. This paper examines a series of visual and written reports of Māori fortification and natural arches dating from the time of James Cook's first voyage to New Zealand in 1769-70. This highlights competing agenda for the role of nature within architecture: whether it should be a source for an abstract vocabulary informing construction, or whether culture should remain the dominant determinant for architectural form. During the eighteenth century there was a blurring of the relationship between art, architecture and nature, which was supported by the conceptual framework of the picturesque. The call within French architectural theory for architecture to be understood as an imitative art derived from the natural world. The natural arch was utilised as evidence to support that there was a natural origin for architectural form.

In "What's in a Name? The First House in New Zealand architectural discourse", Julia Gatley examines the changing nature of references made to the Group and to their First House in Takapuna, 1949-50, in New Zealand architectural discourse. It suggests that for architects who rose to profile in the 1990s, the Group operated as an origin. These practitioners made recourse to the notion of the Group rather than to specific Group houses. Yet there really was a First House. Or was there? This paper destabilises the primacy of the house by showing that the Group were not the ones to elevate the house with the capitalised and categorical name, First House. It identifies the original name, Experimental House, as well as two subsequent name changes, and suggests that the changes in name reflect and reinforce the changing importance attached to the house by critics, historians and commentators.

Reference to nature as a source of architectural inspiration has been an enthusiasm for many architectural theorists and practitioners in Australia, as Paul Hogben notes in "Uncovering the Strategic: The Appeal to Nature in Early Twentieth-Century Architectural Discourse in Australia." This relationship, however, has not been investigated from the point of view of discourse analysis. To initiate this, Michel Foucault's concept of discourse as a strategic activity is deployed to examine the appeal to nature that was a central tenet of architectural writings and papers published in Sydney in the early 20th century. This was a time when a theoretically active group were arguing that architectural design and decoration should be derived from a close study of 'Nature'. This essay identifies the strategic dimensions of this discourse, which it argues were tied to the forging of a position of critical authority over domestic architecture and the powers of professional, aesthetic and commercial legitimisation this could carry. 
In On Adam's House in Paradise, Rykwert uncovered the primitive hut as a perennial theme in the theory and practice of architecture. By contrast with Refiti's and 'Ilaiu's reading of Rykwert, Tim Adams develops the theme of the house as a project renewed and to be renewed endlessly. In "Benoît Goetz: A French Reader of Rykwert's On Adam's House in Paradise" Adams relates Adam's house to the French philosopher Benoit Goetz, who picks up and expands Rykwert's discovery in his book La Dislocation: Architecture et Philosophie. Goetz observes that there could not have been a house in the Garden of Eden because prior to the expulsion from paradise there could not have been any division of places, nor any inside or outside. Paradise lacks nothing so every space in it, Goetz concludes, is equivalent to all other spaces. Paradise is, in other words, an indivisible field of immanence without otherness and without limit. This explains precisely why the primitive hut or first dwelling is so endlessly fascinating: it conveys the fundamental truth that human beings have acquired the sin of knowledge and have thus become increasingly alienated from the continuum of unknowing nature.

Finally, Carl Douglas's "Contract, Crowd, Corpus and Plasma: Architectural and social assemblages" springs from Rykwert's observation, in On Adam's House in Paradise of a conceptual correlation between Marc-Antoine Laugier and JeanJacques Rousseau. It discerns, in the condition of joints in Laugier's Essay on Architecture (1753) and social bonds in Rousseau's Social Contract (1762), an underlying structural logic: what he calls an implicit theory of assemblage. From this initial reference point in the mid-eighteenth century, the paper moves to consider theories of crowds in the late nineteenth century as implicit theories of assemblage, and ultimately advocates the work of Gabriel Tarde as a basis for explication of these underlying theories. 
